ORIGINAL ARTICLE

\title{
Contamination of Mobile Phones of Health Care Workers of PIMS Hospital Islamabad
}

\author{
NIDA KHALIQ ${ }^{1}$, ZILLE HUMA MUSTEHSAN ${ }^{2}$, HANIA RASHID ${ }^{3}$, SHAFAQ KHADIJA ${ }^{4}$, NAZEEHA WASEEM ${ }^{5}$, HAFSA \\ WASEEM ${ }^{6}$ \\ ${ }^{1}$ Lecturer Community Medicine, Fazaia Medical College Air University, Islamabad \\ ${ }^{2}$ Assistant Professor Community Medicine, Fazaia Medical College, Air University, Islamabad \\ ${ }^{3}$ Demonstrator, Fazaia Medical College, Islamabad \\ ${ }^{4}$ Senior Lecturer Histopathology, Fazaia Medical College, Air University, Islamabad \\ ${ }^{5}$ Medical Imaging Doctor, Department of Radiological Sciences and Medical Imaging Technology, University of Lahore, Gujrat \\ ${ }^{6}$ Senior Lecturer Pathology, Fazaia Medical College, Islamabad \\ Corresponding author: Dr. Zille Huma Mustehsan, E-mail: zhmustehsan@gmail.com, Cell No: +923234924397
}

\begin{abstract}
Introduction: Mobile phones are one of the most vital telecommunication devices and are used to stay in touch with both the social and professional aspects of our lives. They have also become an important tool for the rapid delivery of information in healthcare institutions, such as hospitals. However, with many benefits of mobile phone usage, also comes the drawbacks of hospital-associated pathogens surviving on these mobile phone screens.

Objectives: To determine the frequency of contamination of healthcare worker's mobile phones by different types of microorganisms.

Methodology: A cross-sectional study was conducted from June 2020 till December 2020 at PIMS Hospital, a tertiary care hospital located in Islamabad, Pakistan. A total of 121 individual mobile phones were randomly sampled. A simple random sampling method was used. Informed consent was taken before taking a sample and a questionnaire was also utilized.

Results: Among 121 samples collected from different department health workers mobile phone surfaces, 112 showed significant differences $(92.56 \%)$ which were positively contaminated with microorganisms.

Conclusion: To conclude, a high contamination rate of mobile phones was found with microorganisms. This could lead to serious nosocomial infections. Therefore, a standard guideline on the use of electronic devices and mobile phones should be implemented in hospitals and healthcare centres. Enforce the hygiene practices such as washing hands and cleaning mobile phones a few times a day.
\end{abstract}

Keywords: Healthcare Worker, Mobile Phone, Microorganism, Contamination, Disinfectant

\section{INTRODUCTION}

Mobile phones are one of the most vital telecommunication devices in the $21^{\text {st }}$ century after being introduced to the world in 1982 in Europe. Mobile phones are used to stay in touch with both the social and professional aspects of our lives. They have also become an important tool for the rapid delivery of information in healthcare institutions, such as hospitals thus making healthcare delivery a lot more efficient worldwide (1).

However, along with the many benefits of mobile phone usage, comes the drawbacks of hospital-associated pathogens surviving on these mobile phone screens. This could potentially make mobile phones and other hand-held devices that are frequently used in the hospital reservoirs for transmission of diseases (2).

Bacteria are more likely to grow and form colonies on mobile phones since they are constantly pressed against the palms of our hands. The ideal temperature and moisture provided by the human lead to growth of these pathogens and make mobile phones a prime breeding ground for many microorganisms (3).

A study conducted in 2019 on healthcare workers mobile phones showed that the rate of bacterial contamination of mobile phones was $100 \%$. The most frequently isolated bacteria were Coagulase Negative Staphylococcus,Bacillus sp. and Methicillin-resistant Staphylococcus aureus (97\%, 56\%, 17\%, respectively) (4).

The bacteria that were most predominantly found was Coagulase negative Staphylococcus. Coagulase negative
Staphylococci are normal resident microflora on the human body; however, its infections are nosocomial (5).

For this reason, it is importantto determine the surface pathogens present on mobile phone surfaces and make sure that healthcare workers are actively disinfecting them.

Increased awareness about the microorganisms found on mobile phones might encourage people to sanitise their phones often, which will help prevent the transmission of diseases and nosocomial infections. (6)

Objective: To determine the frequency of contamination of healthcare worker's mobile phones by different types of microorganisms

\section{METHODOLOGY}

A cross sectional study was conducted in June 2020 at PIMS Hospital, a tertiary care hospital located in Islamabad, Pakistan. A total of 121 mobile phones were randomly sampled from individuals working in the hospital. A simple random sampling technique was used. Doctors working in the hospital having touch screen mobile phones were also included. Informed consent was taken with the help of a questionnaire that included questions related to the participants personal information (age, gender, department), usage of mobile phone (storage, the use of a screen protector, using it in the washroom etc.). Furthermore, it had questions about mobile phones' disinfection and their usage during interaction with patients or in the operation theatre. A sterile swab moistened with normal saline was used to make an S-shaped pattern on 
the front and back of each smartphone. The swabs were placed in sterile and labelled (serial numbers, source, etc.) containers with a properly filled in proforma of the pathology department of Federal Medical and Dental College. Samples were inoculated on nutrient agar aerobically at $37^{\circ} \mathrm{C}$ for 24 hours. The colony grown on the culture plate the Gram staining procedure was done to identify Gram positive rods and cocci and Gram negative rods and cocci. Then other identification tests like coagulase test, catalase test, motility and oxidase test was performed. Definitive biochemical tests were also performed by using API $10 \mathrm{~S}$ and API 20E (Biomerieux, France) to identify isolate at genus and species level. SPSS version 23 was used to analyse the data.

\section{RESULTS}

A total of 121 samples were collected from different department workers' mobile phones. Among 121 samples, 112 samples showed (92.56\%) significant contamination with microorganisms (Figure 1).

The demographic details of the total participants that took part in this research are shown in Table 1. Compared to females the male participants were dominant $n=67$ $(55.37 \%)$ and females were $n=54$ (44.63\%). Among the participant, $n=59(52.86 \%)$ males and $n=53$ (47.32\%) female's phones were found positively contaminated with microorganisms. Besides this, the participant from the surgery department showed the highest mobile phone contamination rate with microorganisms (41.07\%). The two pathogens Staphylococcus epidermidis and Staphylococcus aureus showed a prevalent manner on both sides of mobile phones, as shown in Table 2 .

Figure 1 Contamination of mobile phones of health care workers

\section{Contamination of mobile phones of HCWs}

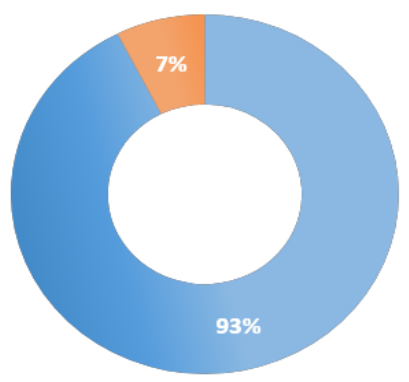

positive for contamination negative for contamination

Table 1: Baseline characteristics

\begin{tabular}{|c|c|c|c|c|c|}
\hline & & Frequency & Percentage & Positive for microbes & Percentage \\
\hline \multirow[b]{2}{*}{ Sex } & Male & 67 & $55.37 \%$ & 59 & $52.68 \%$ \\
\hline & Female & 54 & $44.63 \%$ & 53 & $47.32 \%$ \\
\hline \multirow{4}{*}{ Age group } & $20-30$ & 32 & $26.45 \%$ & 30 & $26.79 \%$ \\
\hline & $30-40$ & 29 & $23.96 \%$ & 27 & $32.14 \%$ \\
\hline & $40-50$ & 37 & $30.58 \%$ & 36 & $24.11 \%$ \\
\hline & $50-60$ & 23 & $19.01 \%$ & 19 & $96 \%$ \\
\hline \multirow{5}{*}{ Designation } & Trainee & 36 & $29.75 \%$ & 34 & $30.36 \%$ \\
\hline & Lecturer & 33 & $27.27 \%$ & 32 & $28.57 \%$ \\
\hline & Assistant professor & 25 & $20.66 \%$ & 24 & $21.43 \%$ \\
\hline & Associate Professor & 18 & $18.88 \%$ & 16 & $14.29 \%$ \\
\hline & Professor & 9 & $7.44 \%$ & 6 & $5.36 \%$ \\
\hline \multirow[t]{4}{*}{ Departments } & Medicine \& Allied & 47 & $38.84 \%$ & 45 & $40.18 \%$ \\
\hline & Surgery & 50 & $41.32 \%$ & 46 & $41.07 \%$ \\
\hline & Basic & 11 & $9.09 \%$ & 9 & $8.04 \%$ \\
\hline & Dentistry & 13 & $10.74 \%$ & 12 & $10.71 \%$ \\
\hline \multirow{6}{*}{$\begin{array}{l}\text { Subspecialty } \\
\text { of Medicine \& } \\
\text { allied }\end{array}$} & General Medicine & 12 & $9.92 \%$ & 12 & $10.71 \%$ \\
\hline & Cardiology & 8 & $6.61 \%$ & 8 & $7.14 \%$ \\
\hline & Pulmonology & 9 & $7.44 \%$ & 8 & $7.14 \%$ \\
\hline & Gastroenterology & 7 & $5.79 \%$ & 6 & $5.36 \%$ \\
\hline & Dermatology & 5 & $4.13 \%$ & 5 & $4.46 \%$ \\
\hline & Nephrology & 6 & $4.96 \%$ & 6 & $5.36 \%$ \\
\hline \multirow{6}{*}{$\begin{array}{l}\text { Subspecialty } \\
\text { of Surgery \& } \\
\text { allied }\end{array}$} & General Surgery & 12 & $9.92 \%$ & 11 & $9.82 \%$ \\
\hline & Orthopaedics & 7 & $5.79 \%$ & 7 & $6.25 \%$ \\
\hline & Gynaecology & 10 & $8.26 \%$ & 10 & $8.93 \%$ \\
\hline & Radiology & 6 & $4.96 \%$ & 3 & $2.67 \%$ \\
\hline & Neurosurgery & 7 & $5.79 \%$ & 7 & $6.25 \%$ \\
\hline & Cardio-thoracic surgery & 8 & $6.61 \%$ & 8 & $7.14 \%$ \\
\hline \multicolumn{2}{|l|}{ Total } & 121 & $100 \%$ & 112 & $100 \%$ \\
\hline
\end{tabular}


Table 2: Cross tabulation of microorganisms on both surfaces of mobile phones of health care workers

\begin{tabular}{|c|c|c|c|c|c|c|c|}
\hline & Pathogens & Trainee & Lecturer & $\begin{array}{l}\text { Assistant } \\
\text { Professor }\end{array}$ & $\begin{array}{l}\text { Associate } \\
\text { Professor }\end{array}$ & Professor & Total \\
\hline \multirow{7}{*}{ Screen } & Staphylococcus epidermidis & $6(5.36 \%)$ & $6(5.36 \%)$ & $5(4.46 \%)$ & $6(5.36 \%)$ & $2(1.79 \%)$ & $25(22 \%)$ \\
\hline & Staphylococcus aureus & $3(2.67 \%)$ & $4(3.57 \%)$ & $2(1.79 \%)$ & $1(0.89 \%)$ & $0 \%$ & $10(9 \%)$ \\
\hline & Micrococcus sp. & $4(3.57 \%)$ & $3(2.67 \%)$ & $1(0.89 \%)$ & $0 \%$ & $1(0.89 \%)$ & $9(8 \%)$ \\
\hline & Bacillus subtilis & $2(1.79 \%)$ & $3(2.67 \%)$ & $3(2.67 \%)$ & $1(0.89 \%)$ & $0 \%$ & $9(8 \%)$ \\
\hline & Pseudomonas aeruginosa & $2(1.79 \%)$ & $3(2.67 \%)$ & $1(0.89 \%)$ & $1(0.89 \%)$ & $1(0.89 \%)$ & $8(7 \%)$ \\
\hline & E. coli & $0 \%$ & $1(0.89 \%)$ & $1(0.89 \%)$ & $1(0.89 \%)$ & $0 \%$ & $3(3 \%)$ \\
\hline & Others & $3(2.67 \%)$ & $2(1.79 \%)$ & $1(0.89 \%)$ & $1(0.89 \%)$ & $0 \%$ & $7(6 \%)$ \\
\hline \multicolumn{2}{|l|}{ Total } & $\begin{array}{l}20 \\
(17.88 \%)\end{array}$ & $\begin{array}{l}22 \\
(19.64 \%)\end{array}$ & $14(12.5 \%)$ & $11(9.82 \%)$ & $4(3.57 \%)$ & $\begin{array}{l}71 \\
(63 \%\end{array}$ \\
\hline \multirow[t]{7}{*}{ Backside } & Staphylococcus epidermidis & $4(3.57 \%)$ & $3(2.67 \%)$ & $3(2.67 \%)$ & $2(1.79 \%)$ & $0 \%$ & $12(11 \%)$ \\
\hline & Staphylococcus aureus & $2(1.79 \%)$ & $1(0.89 \%)$ & $1(0.89 \%)$ & $2(1.79 \%)$ & $1(0.89 \%)$ & $7(6 \%)$ \\
\hline & Micrococcus sp. & $2(1.79 \%)$ & $2(1.79 \%)$ & $2(1.79 \%)$ & $1(0.89 \%)$ & $0 \%$ & $7(6 \%)$ \\
\hline & Bacillus subtilis & $2(1.79 \%)$ & $2(1.79 \%)$ & $2(1.79 \%)$ & $0 \%$ & $1(0.89 \%)$ & $7(6 \%)$ \\
\hline & Pseudomonas aeruginosa & $2(1.79 \%)$ & $1(0.89 \%)$ & $1(0.89 \%)$ & $0 \%$ & $0 \%$ & $4(4 \%)$ \\
\hline & E. coli & $1(0.89 \%)$ & $0 \%$ & $0 \%$ & $0 \%$ & $0 \%$ & $1(1 \%)$ \\
\hline & Others & $1(0.89 \%)$ & $1(0.89 \%)$ & $1(0.89 \%)$ & $0 \%$ & $0 \%$ & $3(3 \%)$ \\
\hline \multicolumn{2}{|l|}{ Total } & $14(12.5 \%)$ & $10(8.93 \%)$ & $10(8.93 \%)$ & $5(4.46 \%)$ & $2(1.79 \%)$ & \\
\hline \multirow{7}{*}{$\begin{array}{l}\text { Total } \\
\text { (both } \\
\text { surfaces) }\end{array}$} & Staphylococcus epidermidis & $10(8.93 \%)$ & $9(8.04 \%)$ & $8(7.14 \%)$ & $8(7.14 \%)$ & $2(1.79 \%)$ & $37(33 \%$ \\
\hline & Staphylococcus aureus & $5(4.46 \%)$ & $5(4.46 \%)$ & $3(2.67 \%)$ & $3(2.67 \%)$ & $1(0.89 \%)$ & $17(15 \%)$ \\
\hline & Micrococcus sp. & $6(5.36 \%$ & $5(4.46 \%)$ & $3(2.67 \%)$ & $1(0.89 \%)$ & $1(0.89 \%)$ & $16(14 \%)$ \\
\hline & Bacillus subtilis & $4(3.57 \%)$ & $5(4.46 \%)$ & $5(4.46 \%)$ & $1(0.89 \%)$ & $1(0.89 \%)$ & $16(14 \%)$ \\
\hline & Pseudomonas aeruginosa & $4(3.57 \%)$ & $4(3.57 \%)$ & $2(1.79 \%)$ & $1(0.89 \%)$ & $1(0.89 \%)$ & $12(11 \%)$ \\
\hline & E. coli & $1(0.89 \%)$ & $1(0.89 \%)$ & $1(0.89 \%)$ & $1(0.89 \%)$ & $0 \%$ & $4(4 \%)$ \\
\hline & Others & $4(3.57 \%)$ & $3(2.67 \%)$ & $2(1.79 \%)$ & $1(0.89 \%)$ & $0 \%$ & $10(9 \%)$ \\
\hline \multicolumn{2}{|l|}{ Total } & $\begin{array}{l}34 \\
(30.36 \%)\end{array}$ & $\begin{array}{l}32 \\
(28.57 \%)\end{array}$ & $\begin{array}{l}24 \\
(21.43 \%)\end{array}$ & $\begin{array}{l}16 \\
(14.29 \%)\end{array}$ & $6(5.36 \%)$ & \\
\hline
\end{tabular}

\section{DISCUSSION}

Mobile phones are used extensively by most individuals in the world today. This includes healthcare workers and it has had a significant impact on the efficiency with which healthcare systems provide services to patients these days. However, nosocomial infections caused by multidrug resistant organisms are growing problems in many hospitals and healthcare institutions $(7,8)$. Previous studies show that since mobile phones are portable, they are often used in close proximity to patients, thus making these patients more endangered to the possibility of nosocomial infection $(9,10)$.

In our study 121 mobile phones were randomly sampled from individuals working in PIMS Hospital. We found that 112 samples (92.56\%) were positively contaminated with microorganisms. This concordance with a previous study in which $69 \%$ of the samples taken from mobile phones of health care workers were positive for contamination (11). Furthermore, our findings suggest that Staphylococcus epidermidis and Staphylococcus aureus are the two pathogens that are most prevalent on both the front screen and backside of mobile phones. This result validates the conclusions of another study done in 2016 where they found the prevalence rate of Staphylococcus epidermidis to be $84 \%$ and Staphylococcus aureus to be $54 \%(12)$.

Previous studies show that cleaning computers and telephones with $70 \%$ isopropyl can reduce bacterial contamination $(13,14)$. It is suggested that simply using other people's mobile phones leads to more chances of being infected with a bacterial pathogen (15). Therefore, various disinfection methods should be studied in the future to help determine which is the most efficacious $(16,17)$. Keeping the recent Covid-19 pandemic in mind it is important now more than ever to help prevent nosocomial infections by issuing standard guidelines about the hygiene practices of electronic devices and mobile phones in hospital (18).

\section{CONCLUSION}

To conclude, mobile phones were found to be highly contaminated with microorganisms. This could lead to nosocomial infections and a standard guideline should be issued about the hygiene practices of electronic devices and mobile phones in hospitals and healthcare centres. Cleaning and disinfecting protocols should be followed and maintained to reduce the unnecessary exposure of patients to microorganisms.

Recommendations: Screening of mobile phones for contamination by microorganisms should be done regularly especially within hospital areas (19). Mobile phones should not be used while interacting with patients and in healthcare settings to reduce the risk of transmission of nosocomial infection. Further studies may be conducted based on the results from our data. A study could be conducted on the rate of contamination of patients by nosocomial infections and the microbes found on their respective doctors and nurses' mobile phones. This could directly prove the number of nosocomial infections that are caused by the use of mobile phones by healthcare workers in hospital settings. Another study could be conducted on the number of nosocomial infections in different departments of a hospital comparing that with how lax the rules of usage of mobile phones are around patients in that 
specific department. Various disinfection methods of mobile phones and antimicrobial gels could be studied to find the most effective method, including the difference of microorganisms found on the phones that have been disinfected (20). Further research could also be conducted, to determine if there is a significant overlap with the skin microbiome and mobile phones (21) plus the identification and isolation of microorganisms from different parts of the phone (22).

Limitations: Since mobile phones are often used by the entire family including children, this could make them a potentially dangerous vector. However, due to a lack of resources and time we were not able to study the effects of microbial contamination on health care workers' families. We were also not able to find out if multiple colonies and multi-drug resistant bacteria were present on mobile phones of health care workers (23).

Conflict of Interest: There is no conflict of interest declared by any author.

\section{REFERENCES}

1. Kotris I, Drenjanèeviæ $\mathrm{D}$, Talapko J, Bukovski S. Identification of microorganisms on mobile phones of intensive care unit health care workers and medical students in the tertiary hospital. Medicinskiglasnik. 2017 Feb 1;14(1).

2. Olsen $M$, Campos $M$, Lohning $A$, Jones $P$, Legget $J$, Bannach-Brown A, McKirdy S, Alghafri R, Tajouri L. Mobile phones represent a pathway for microbial transmission: a scoping review. Travel medicine and infectious disease. 2020 Apr 28:101704.

3. Rozario SR, Rahman $\mathrm{H}$, Fakhruddin AN, Rabbani KA. Prevalence of multidrug-resistant bacteria on mobile phone surface. Journal of microscopy and ultrastructure. 2020 Jan;8(1):14.

4. Galazzi A, Panigada M, Broggi E, Grancini A, Adamini I, Binda F, Mauri T, Pesenti A, Laquintana D, Grasselli G. Microbiological colonization of healthcare workers' mobile phones in a tertiary-level Italian intensive care unit. Intensive and Critical Care Nursing. 2019 Jun 1;52:17-21.

5. Shi L, Wu D, Wei L, Liu S, Zhao P, Tu B, Xie Y, Liu Y, Wang $X$, Liu L, Zhang $X$. Nosocomial and community-acquired spontaneous bacterial peritonitis in patients with liver cirrhosis in China: comparative microbiology and therapeutic implications. Scientific reports. 2017 Apr 6;7(1):1-9.

6. CicciarellaModica D, Maurici M, D’Alò GL, Mozzetti C, Messina A, Distefano A, Pica F, De Filippis P. Taking screenshots of the invisible: a study on bacterial contamination of mobile phones from university students of healthcare professions in Rome, Italy. Microorganisms. 2020 Jul;8(7):1075.

7. Karkee $P$, Madhup SK, Humagain P, Thaku N, Timilsina B. Mobile phone: A possible vector of bacterial transmission in hospital setting. Kathmandu Univ. Med. J. 2017 Jul 1;15:217-21.

8. Bobat R, Archary M, Lawler M, Mawlana S, Naidoo KL, Maphumulo S, Coovadia Y. The presence and spectrum of bacteria colonising mobile phones of staff and caregivers in high disease burden paediatric and neonatal wards in an urban teaching hospital in Durban, South Africa. Southern African Journal of Infectious Diseases. 2017 Mar 23;32(1):911.
9. Pérez-Cano HJ, Santos MR, Moreno BC. Microbiota in mobile phones of medical ophthalmologists. Archivos de la Sociedad Española de Oftalmología (English Edition). 2019 Feb 1;94(2):55-9.

10. Cobb A, Lazar B. Mobile device usage contributes to nosocomial infections. Radiologic technology. 2020 Jan 1;91(3):303-7.

11. Debnath $\mathrm{T}$, Bhowmik S, Islam T, Chowdhury MM. Presence of multidrug-resistant bacteria on mobile phones of healthcare workers accelerates the spread of nosocomial infection and regarded as a threat to public health in Bangladesh. Journal of microscopy and ultrastructure. 2018 Jul;6(3):165.

12. Kadhem HS, Abed Ali AA, Hassan OM. Isolation and identification of bacteria isolated from different parts of cell phones. World J ExpBiosci. 2016;4(1):29-31.

13. Shaebth LJ. Contamination of Portable Phones with Pathogenic Bacteria, A Comparative Study between Staff at Al Hussain Teaching Hospital and Staff at Samawa Technical Institute. Indian Journal of Forensic Medicine \& Toxicology. 2019 Apr 1;13(2):369-72.

14. Mohanram K, Madanagopal S, Swaminathan P. Isolation and identification of bacterial flora associated with mobile phones of health care professionals. International Journal of Research in Pharmaceutical Sciences. 2018;9(4):1257-61.

15. Abbas SZ. Mobile Phones is a Source of Spreading Bacterial Diseases in (Rawalpindi-Pakistan). Int $\mathrm{J}$ Biotech \&Bioeng. 2018;4(5):113-6.

16. Koscova J, Hurnikova Z, Pistl J. Degree of bacterial contamination of mobile phone and computer keyboard surfaces and efficacy of disinfection with chlorhexidine digluconate and triclosan to its reduction. International journal of environmental research and public health. 2018 Oct;15(10):2238.

17. Guridi A, Sevillano E, de la Fuente I, Mateo E, Eraso E, Quindós G. Disinfectant activity of a portable ultraviolet C equipment. International journal of environmental research and public health. 2019 Jan;16(23):4747.

18. Panigrahi SK, Pathak VK, Kumar MM, Raj U. Covid-19 and mobile phone hygiene in healthcare settings. BMJ global health. 2020 Apr 1;5(4):e002505.

19. Bodena D, Teklemariam Z, Balakrishnan S, Tesfa T. Bacterial contamination of mobile phones of health professionals in Eastern Ethiopia: antimicrobial susceptibility and associated factors. Tropical medicine and health. 2019 Dec;47(1):1-0.

20. Helmi NR, Zaman RM. Isolation of bacteria from mobile phones before and after decontamination: study carried out at King Abdulaziz University, Jeddah, Saudi Arabia. African Journal of Microbiology Research. 2017 Sep 21;11(35):1371-8.

21. Martina PF, Martinez M, Centeno CK, Von Specht M, Ferreras J. Dangerous passengers: multidrug-resistant bacteria on hands and mobile phones. Journal of preventive medicine and hygiene. 2019 Dec;60(4):E293.

22. Kadhem HS, Abed Ali AA, Hassan OM. Isolation and identification of bacteria isolated from different parts of cell phones. World J ExpBiosci. 2016;4(1):29-31.

23. Rozario SR, Rahman H, Fakhruddin AN, Rabbani KA. Prevalence of multidrug-resistant bacteria on mobile phone surface. Journal of microscopy and ultrastructure. 2020 Jan;8(1):14. 